\title{
Continuity of European Languages from the Point of View of DNA Genealogy
}

\author{
Anton Perdih ${ }^{1}$ \\ ${ }^{1}$ Faculty of Chemistry and Chemical Technology, University of Ljubljana, Slovenia (retired) \\ Correspondence: Anton Perdih, Faculty of Chemistry and Chemical Technology, University of Ljubljana, Slovenia.
}

Received: October 30, 2017

Accepted: November 20, $2017 \quad$ Available online: November 23, 2017

doi:10.11114/ijsss.v6i1.2809

URL: https://doi.org/10.11114/ijsss.v6i1.2809

\begin{abstract}
The combination of linguistic and DNA Genealogy data indicates that the aboriginal Europeans, the Y Chromosome haplogroup I people were the Proto-Indo-Europeans and the Proto-Slavic speakers. In contact with newcomers of other language groups mixing took place. Either the newcomers were absorbed into the autochthonous Proto-Slavic community, or the native Proto-Slavic population was so effected by the immigrants that they lost their Slavic identity and formed a language, which remained Indo-European but no longer recognizable as specifically Slavic. The Kurgan Theory and the Pontic Steppe Theory of the Indo-European origin failed completely. The Neolithic Discontinuity Theory theory gives only a part of the necessary explanation. The Paleolithic Continuity Paradigm is superior to them, but it has to be adapted to the data presented by the DNAGenealogy about the timeframe and probable localities of past events.
\end{abstract}

Keywords: DNA Genealogy, origin of humankind, development of humankind, Proto-Indo-Europeans, Proto-Slavs

\section{Introduction}

In December 2016, Mario Alinei and Francesco Benozzo presented an introduction in progress to The Paleolithic Continuity Paradigm for the Origins of Indo-European Languages (Alinei \& Benozzo, 2016). In it they presented also the part 2.4 Genetics, where they cite the genetic data published till 2006. This is just the time when a new branch of genetics, the DNA Genealogy, started to be developed (Klyosov, 2009a,b). Within this decade, the DNA Genealogy presented a substantial quantity of new data, which should be taken into account when considering the origin of Europeans, their languages as well as the areas and the time frames of continuity of European languages.

The overview of these new data till 2016 and their meaning for the origin of Europeans and the de velopment of their languages was published (Perdih, 2016), but afterthem there appeared new important publications, which shed additional light to these questions. The DNA Genealogy data were used also to explain similarities of the words for the animal elephant across Eurasia and Africa (Jandáček \& Perdih, 2017).

For the start of understanding of development of humankind are especially important the following pieces of data:

\subsection{The Ancestors of Present Humankind}

The ancestors of present humankind did not develop in Africa about 50,000 to 100,000 years ago but elsewhere (Klyosov \& Rozhanskii, 2012b, Klyosov, Rozhanskii, \& Ryabchenko, 2013, Klyosov, 2014a), where they had common ancestors from which there split the Denisovans about 800,000 (657,000 to 973,000) years ago and Neanderthals about 400,000 (326,000 to 482,000) years ago (Fu et al., 2013).

1.2 Trunk of the Old Genealogical Tree of Humankind Derived from the YFull Database (Klyosov, 2014c: 1849, YFull, 2017)

The trunk of the old genealogical tree of humankind presents the data of when and from which predecessor derive the $\mathrm{Y}$ Chromosome haplogroups known at present.

The "oldest" haplogroup known at present is the African haplogroup A00 L1284 formed about 235,900 years ago, but it is not the ancestor of any other haplogroup known at present. The same holds true for the African haplogroups A1 a M31 formed about 133,400 years ago, A0 L991 (no data), A1b1 L419 formed about 130,700 years ago, and B M60 formed about 88,000 years ago. 
The ancestor of haplogroup B M60 and of all the other presently known Y Chromosome haplogroups, i.e. haplogroups C through T, was the haplogroup BT M91, which formed about 130,700 years ago from the same ancestor as the presently African haplogroup A1b1 L419.

Haplogroup BT M91 suffered a bottleneck event about 64,000 \pm 6,000 years ago. Its non-African descendant (in parentheses the approximate time of its formation in years ago) was the haplogroups CT M168 $(88,000)$ from which derived the haplogroup DE M145 $(68,000)$ (and its descendant haplogroups D M174 $(65,200)$ and E M96 $(65,200)$ ) as well as the haplogroup CF P143 $(68,500)$. From the haplogroup CF P143 there formed the haplogroup C M130 $(65,900)$ and F M89 $(65,900)$. From the haplogroup F M89 derived in one or another sequence all the other haplogroups known at present, for example G M201 (48,500), H L901 (48,500), I M170 (42,900), J M304 (42,900), K M9 (47,200). From the haplogroup K M9 there formed haplogroup P P295 (45,400), L M20 (42,600), T M184 (42,600), N M23 $(36,800)$, and O M175 (36,800). From the haplogroup P P295 there formed the haplogroup R M207 $(31,900)$ and Q M242 $(31,900)$. From the haplogroup R M207 formed the haplogroup R1 M173 $(28,200)$, and from it the haplogroup R1a M420 (22,800) and R1b M $343(22,800)$.

In Europe are now the most frequent the haplogroups I, R1a, R1b, E, and $\mathrm{N}$ with substantial variations between different areas. A collection of these data is available at ydna.eu.

1.3 Cosmogenic Mega-tsunami of 71,000 to 57,000 Years Ago, Most Probably 68,000 Years Ago, Coincident with MIS 4 (Yurkovets, 2015, Yurkovets \& Vasilenko, 2017)

About 68,000 years ago a big cosmic body fell into the Pacific Ocean causing a wave many kilometers high. It flooded most of the continents, Map 1, except the East African Highlands and the region in Alps and Balkans in Europe. It is not yet clear whether it caused the Toba eruption or they were two independent events. However, the impact of a cosmic body in Russia about 40,000 years ago, which formed the Ladoga Lake and which ashes devastated the Russian Plane, caused the eruption of the Caucasian and Mediterranean vulcanos (Yurkovets, 2012, 2014).

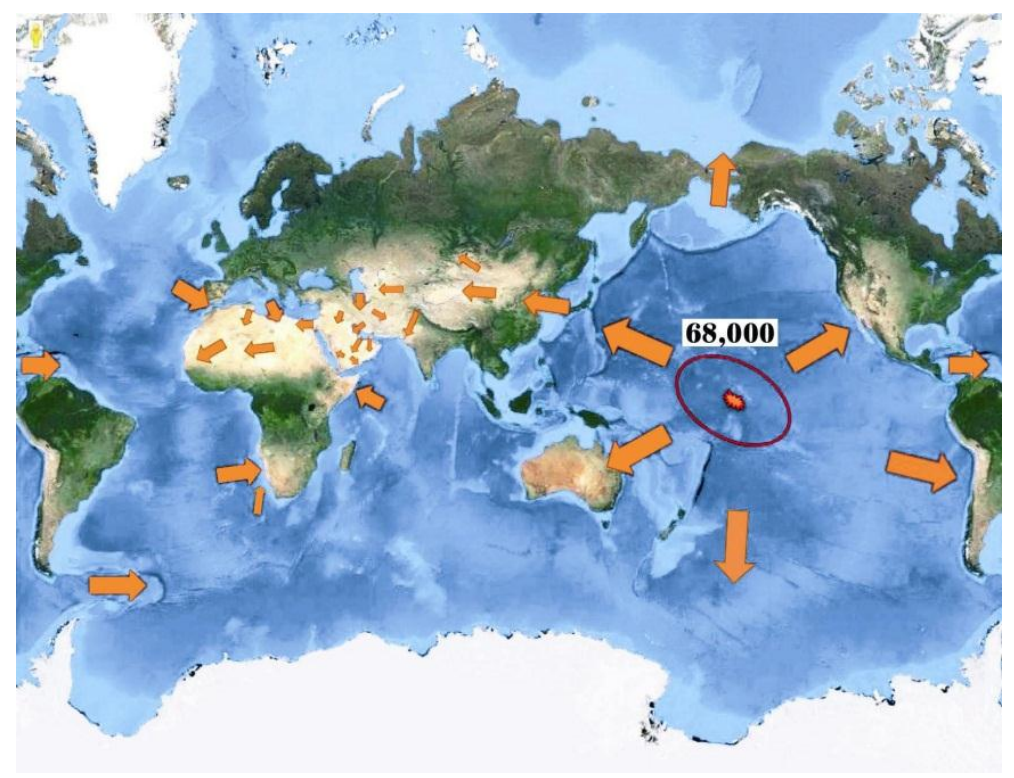

Map 1. Areas of influence of the cosmogenic mega-tsunami about 68,000 (71,000 to 57,000) years ago according to the morphology of its traces (Yurkovets, 2015, Yurkovets \& Vasilenko, 2017)

\subsection{Haplogroups in European Skeletons of about 30,000 Years Ago and Later (Fu et al., 2016)}

In those skeletons (in the Czech Republic, Rumania, Russia, Germany, Belgium, Spain, Italy) there were discovered the Y Chromosome haplogroups BT, CT, C, F, I and the haplogroups HIJK and IJK, which derived from the haplogroup F and which are ancestors of haplogroup I.

\section{Results}

Putting together these four groups of data gives rise to the following conclusion, illustrated in Map 2: 


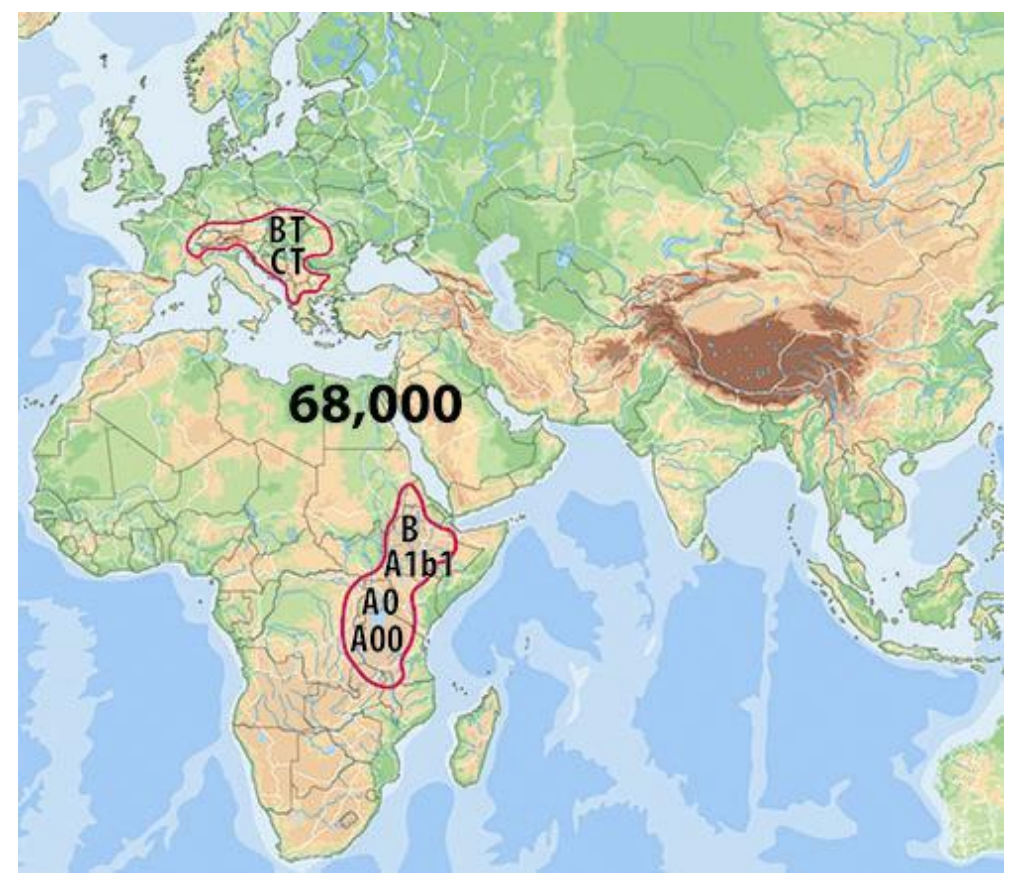

Map 2. Areas of humankind survival on the cosmogenic mega-tsunami event about 68,000 years ago. Given are the $Y$ Chromosome haplogroups of the survivors

As shown on the Map 2, on the East African Highlands there survived the males having Y Chromosome haplogroups A00, A0, A1b1 and B together with their females. In the region in Alps and Balkans in Europe there survived the males having Y Chromosome haplogroups BT and CT with their females having the mtDNA haplogroup U. There is still open the question whether some humans survived in the Caucasus Mountains and/or Himalayas.

After this event the African survivors expanded across most of Africa. The European survivors expanded subsequently across Eurasia, entered Americas, Australia, and the males having the Y Chromosome haplogroup E entered Africa, where it is now the main haplogroup.

These expansions are illustrated schematically in Map 3 through 11 drawn on the basis of data in references. The spread of the Y Chromosome haplogroups $\mathrm{C}$ through T, based on the starting-point presented in Map 2 and on the position at present is schematically presented in Map 3 for the Y Chromosome haplogroups D and E, in Map 4 for the $\mathrm{Y}$ Chromosome haplogroup C, in Map 5 for the Y Chromosome haplogroup F and its descendants the Y Chromosome haplogroups G, H, I, J, K. In Map 6 is presented the Y Chromosome haplogroup K and its descendants the Y Chromosome haplogroups P, Q, R as well as LT, T, L, NO, N, O, M and S.

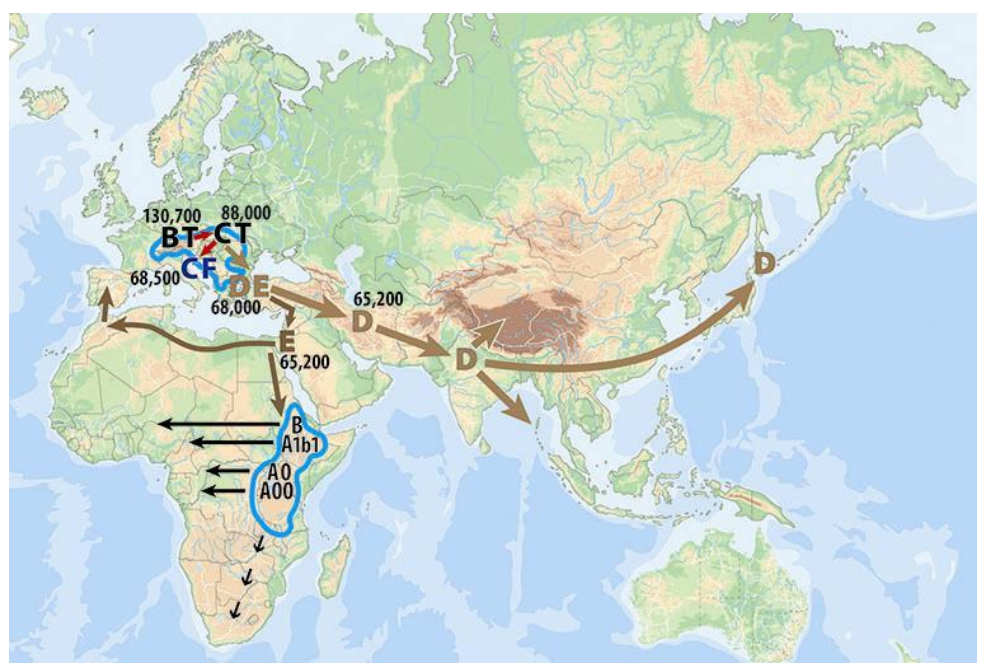

Map 3. Formation and expansion of people having the YChromosome haplogroup D, which are observed now mainly in Tibet, Andaman Islands and Japan, as well as of the people having the Y Chromosome haplogroup E, which are observed now mainly in Near East and Africa, but also in Europe 
Where formed the Y Chromosome haplogroup DE from CT, Map 3, is not known yet nor the exact ways of expansion of the YChromosome haplogroups D and E. The Y Chromosome haplogroup D is observed now mainly in Tibet, on the Andaman Islands and in Japan. The people having the Y Chromosome haplogroup E are observed now mainly in the Near East, Europe, and especially in Africa, where this is the most frequent haplogroup.

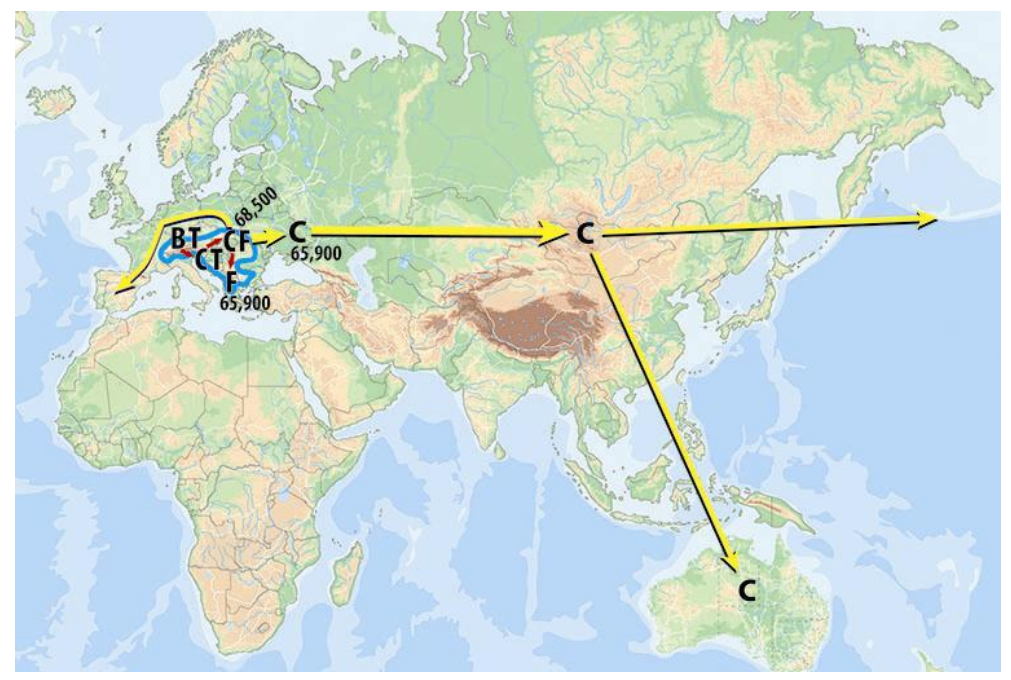

Map 4. Formation and expansion of people having the Y Chromosome haplogroup C, which are observed now mainly in Central Asia, among the Aborigins in Australia and America

The Y Chromosome haplogroup C, Map 4, seems to had been formed in Europe, since it has been discovered in some ancient skeletons in Europe (Fu et al., 2016), where it seems now to be extinct. The Y Chromosome haplogroup C is now characteristic for Mongols, some American Indios and Australian Aborigins.

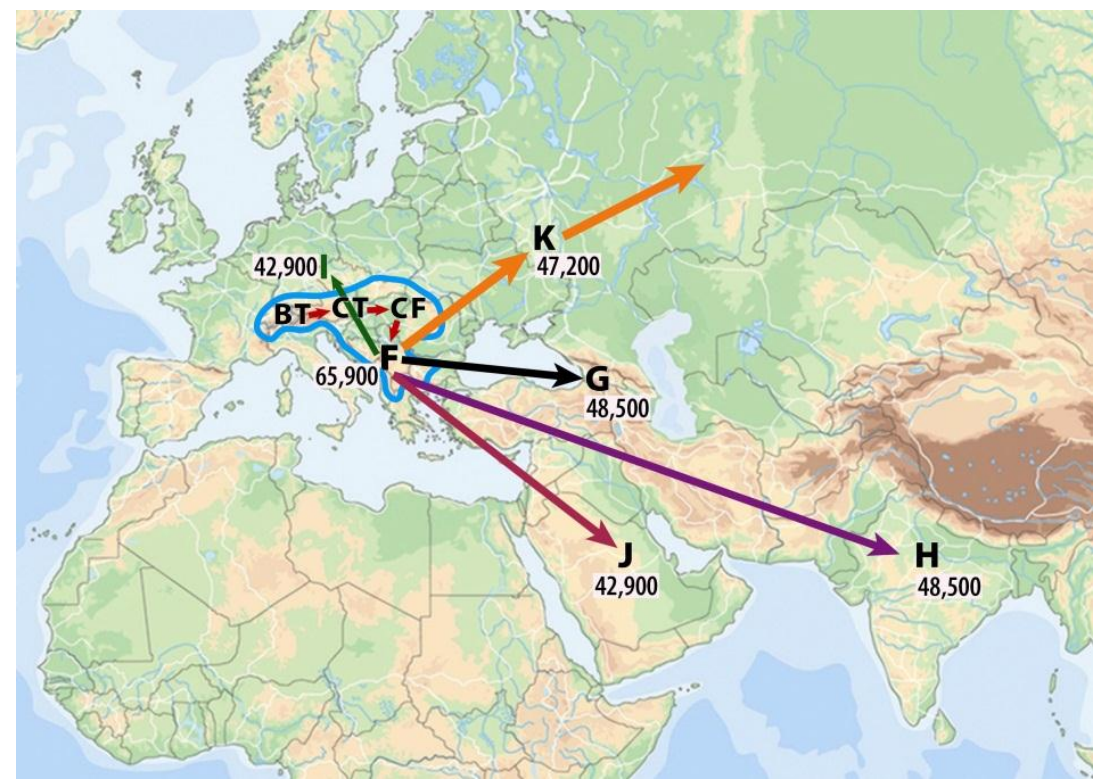

Map 5. Formation of people having the Y Chromosome haplogroup F and expansion of its descendants

The Y Chromosome haplogroup F, Map 5, seems to had been the most successful one since from it formed the most extant haplogroups $(\mathrm{G}, \mathrm{H}, \mathrm{I}, \mathrm{J}, \mathrm{K})$ and their descendants represent now the majority of humankind. The Y Chromosome haplogroup $\mathrm{F}$ has been discovered in ancient skeletons in Europe (Fu et al., 2016) but now it is very rare. Also the Y Chromosome haplogroup I has been discovered in ancient skeletons in Europe (Fu et al., 2016). Its past and present situation presented Klyosov(2010a, 2011a, 2012b, 2015b). 


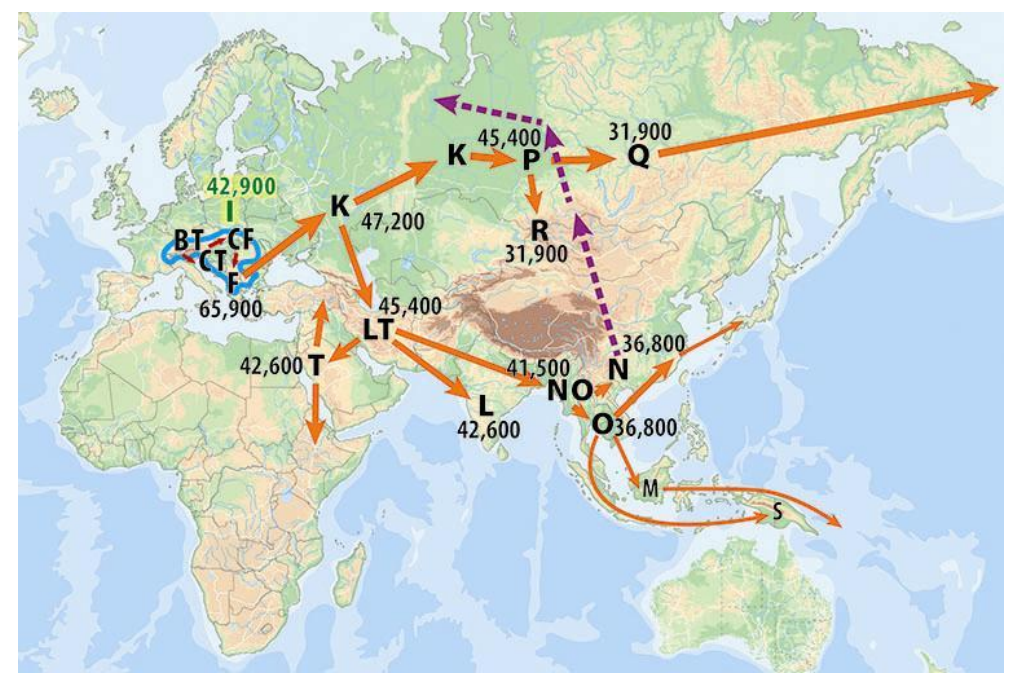

Map 6. Formation and expansion of people having the Y Chromosome haplogroup $\mathrm{K}$ as well as of its descendants One of the descendants of the Y Chromosome haplogroup F, namely the haplogroup K, Map 6, was very productive as well. It is now very rare, as well, but its descendants we find all over the world. The Y Chromosome haplogroup $\mathrm{K}$ seems to had expanded east. From it there formed the haplogroup LT $(45,400)$, which expanded south, whereas in Siberia there formed the haplogroup $\mathrm{P}(45,400)$.

From the haplogroup LT there formed the haplogroup T $(42,600)$, which members live from Ethiopia to Estonia, then haplogroup L (42,600), which members live in India and Middle East, and the haplogroup NO (41,500), which migrated to the South East Asia. There formed from the haplogroup NO the haplogroups N (36,800) and O (36,800) The haplogroup $\mathrm{O}$ is now the main haplogroup there (China, Tibet, Vietnam, Cambodia, Japan), whereas part of the members of haplogroup $\mathrm{N}$ migrated north.

From the haplogroup P there formed the haplogroup Q $(31,900)$, which descendants live now in North East Asia and in Americas, as well as the haplogroup R $(31,900)$, which members remained mainly in the Altai region, and there formed from the haplogroup R the haplogroup R1 (28,200), and from it the haplogroup R1a M420 (22,800) and R1b M 343 $(22,800)$.

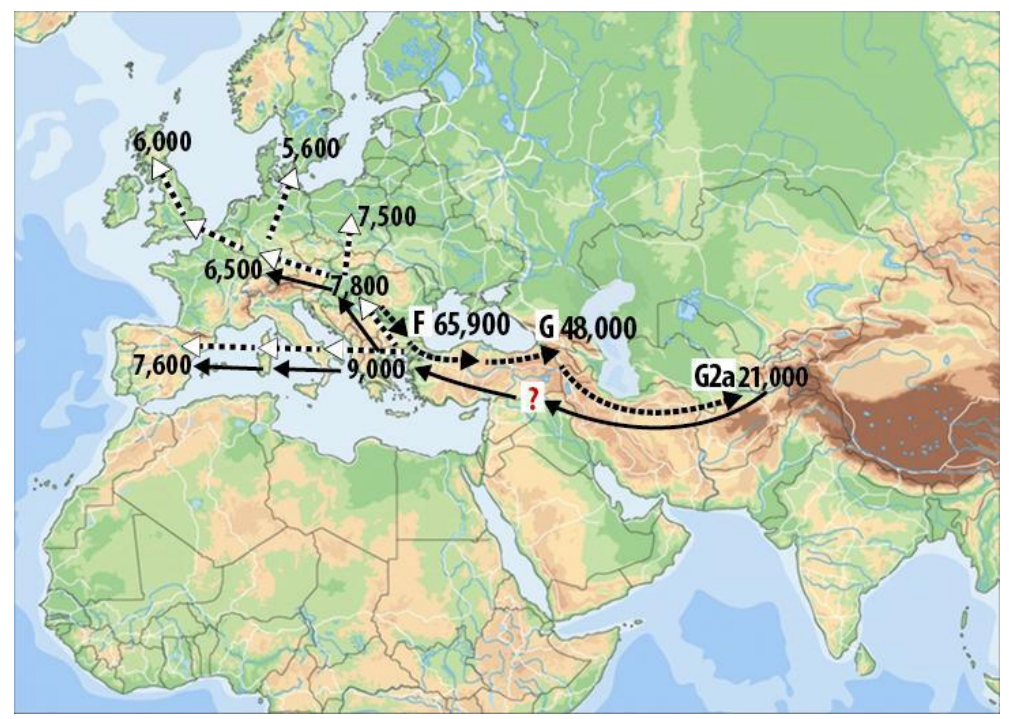

Map 7. Formation and expansion of people having the Y Chromosome haplogroup G. Dotted line - primary expansion, full lines - secondary expansion (Klyosov, 2012c, 2016c, Rozhanskii, 2016). White pointed arrows: Formation and expansion of agriculture (Zohary \& Hopf, 2004)

The Y Chromosome haplogroup G, Map 7, formed from haplogroup F somewhere between the Balkans and the Caucasus. It expanded east, and near or in present Afghanistan there formed the haplogroup G2a (Klyosov, 2016c), 
which subsequently expanded west and it was one of the bearers of agriculture into Europe. On intrusion of the Y Chromosome haplogroup R1b people into Europe about 4,500 years ago, it was largely exterminated and the rest of its bearers remained there, whereas most of its bearers live now in western Caucasus, especially in Ossetia, but the majority of them have non-European subgroups of the Y Chromosome haplogroup G2a (Rozhanskii, 2016).

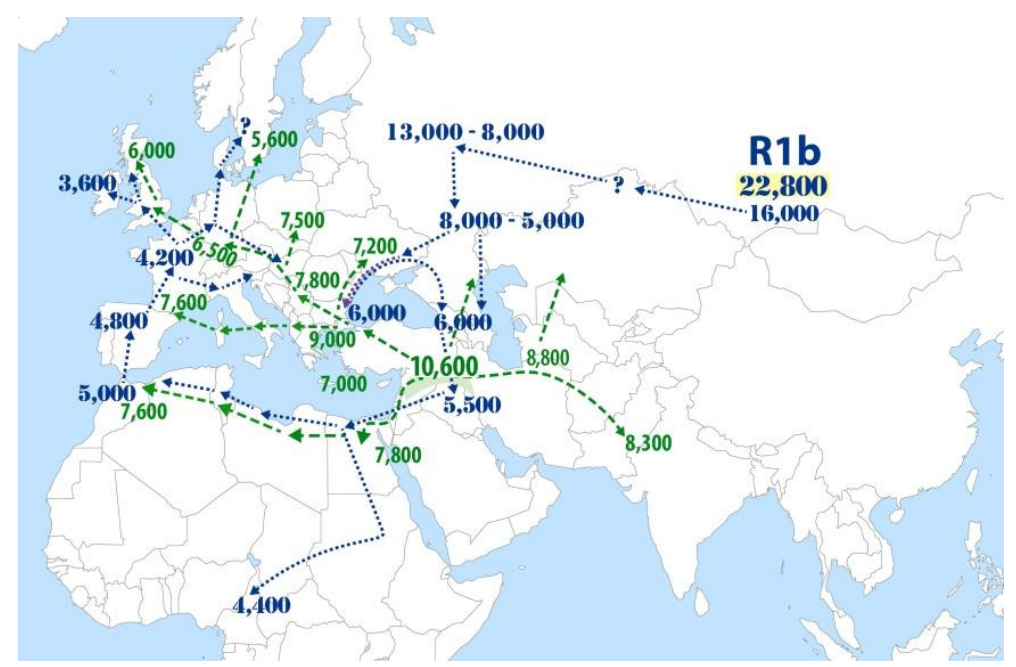

Map 8. Formation and expansion of people having the Y Chromosome haplogroup R1b (Klyosov, 2008, 2009c, 2010b, 2011a,b,d, 2012a, 2013, 2014b). In green: Formation and expansion of agriculture (Zohary \& Hopf, 2004)

In Central Asia there formed from the haplogroup R (31,900 years ago) the haplogroup R1 $(28,200)$, and from it the haplogroup R1a $(22,800)$ and R1b $(22,800)$. After the LGM, the people having haplogroup R1 b, Map 8, migrated west and settled the Middle Volga River region about 13,000 years ago, where they formed the Pre-Kurgan and Kurgan cultures. Gradually they expanded south. Those who remained north of the Caucasus Mountains about 6,000 years ago formed later the Yamna Culture etc., and did not advance west into the Central or Western Europe but south till Mesopotamia. Those who advanced beyond the Caucasus Mountains about 6,000 years ago reached the Mesopotamia and founded there the Sumerian state. From there some of them migrated west into Egypt, where they were the founders of the Pharaoh system. From Egypt they continued south into Central Africa and west across the Northern Africa. About 4,900 years ago they entered the Iberian penninsula and from there they as the bearers of the Bell Beaker culture conquered the Western Europe till the Ireland and Scandinavia, intruding also the Central Europe (Klyosov, 2008, 2009c, 2010b, 2011a,b,d, 2012a, 2013, 2014b).

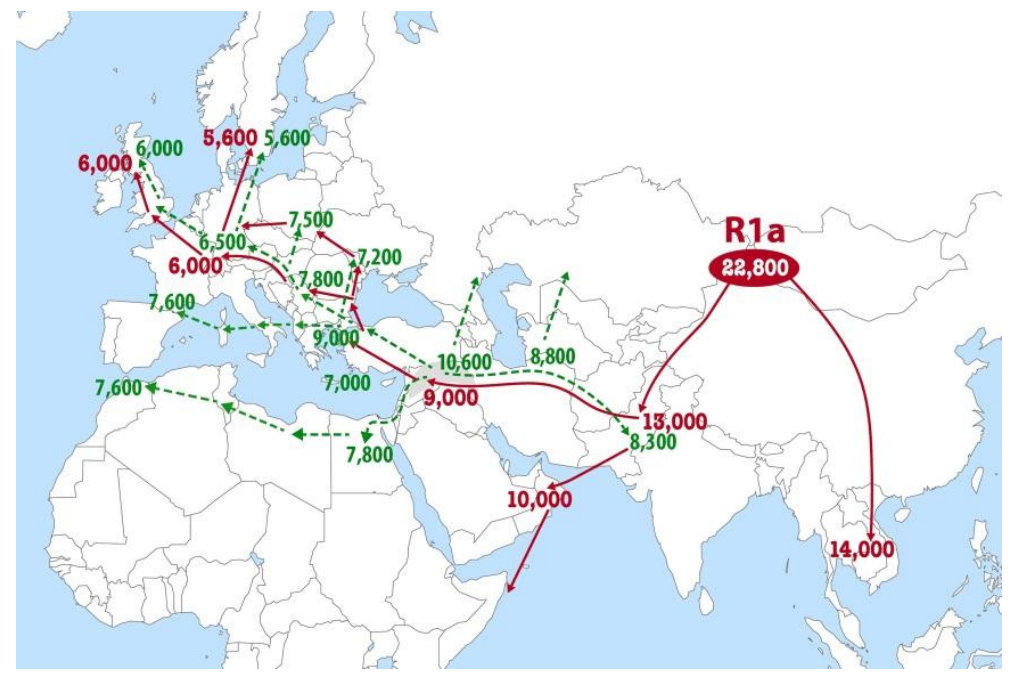

Map 9. Formation and expansion of people having the Y Chromosome haplogroup R1a (Rozhanskii \& Klyosov, 2009, 2012, Klyosov \& Rozhanskii, 2012a, Klyosov, 2014c, 2015a, 2016a,b). In green: Formation and expansion of agriculture (Zohary \& Hopf, 2004)

As the haplogroup R1b $(22,800)$, also the haplogroup R1a $(22,800)$ formed from the haplogroup R1 $(28,200)$. After the LGM, the people having haplogroup R1a, Map 9, migrated southeast till present Cambodia, and the majority of them 
southwest reaching India about 13,000 years ago, eastern Arabia about 10,000 years ago, the Fertile Crescent, Anatolia and the Balkans about 9,000 years ago. They reached the westernmost and the northern Europe till about 6,000 to 5,600 years ago (Rozhanskii \& Klyosov, 2009, 2012, Klyosov \& Rozhanskii, 2012a, Klyosov, 2014c, 2015a, 2016a, b). It is not yet definitely clear which ways they advanced and which ways of living they performed in which of their ways.

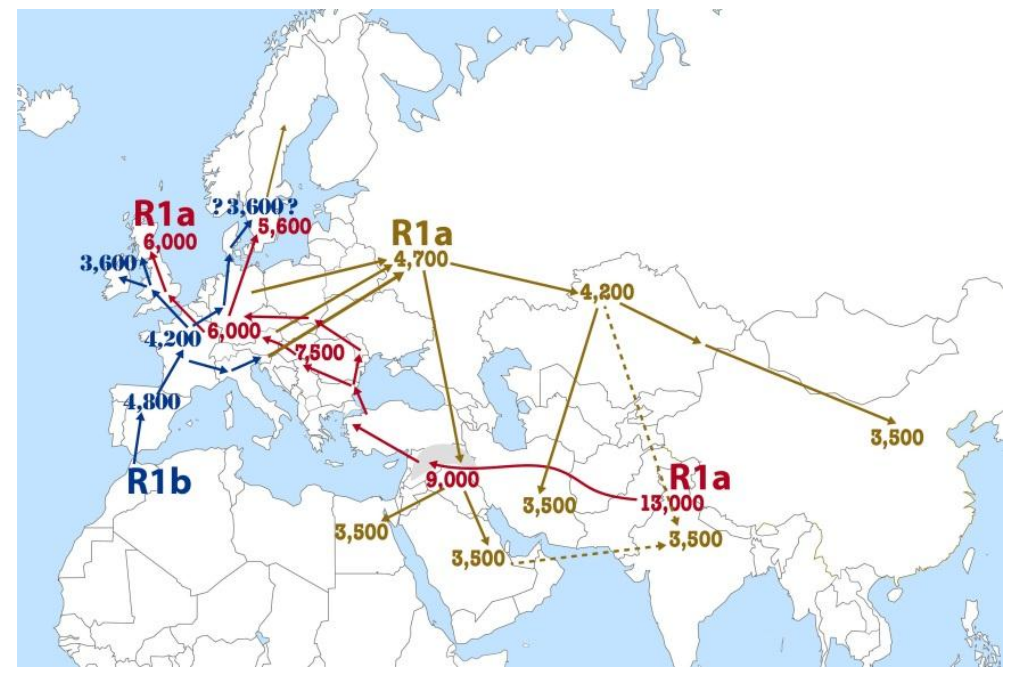

Map 10. On the attacks of people having the Y Chromosome haplogroup R1b the escape of people having the $\mathrm{Y}$ Chromosome haplogroup R1a from the Western and Central Europe onto the Russian Plane and their subsequent expansion into the Near East, Arabia, Iran, northern China and India

After the attacks by the Y Chromosome haplogroup R1b people, Map 10, a number of them escaped from the Western and Central Europe onto the Russian Plane. From the Russian Plane they expanded east as far as Northern China, south to the Near East (Mitanni), Arabia, Iran (Avestians), and India (Aryans) (Rozhanskii \& Klyosov, 2009, 2012, Klyosov \& Rozhanskii, 2012a, Klyosov, 2014c, 2015a, 2016a,b). These genetic data indicate that a substantial part of the extant East Slavs, as well as the Avestians in Iran and Aryans in India derived from the Central Europe after being attacked there.

There is a general opinion that the Y Chromosome haplogroup N people (Finno-Ugric) were the aboriginal inhabitants of the northern Europe. Genetic data, e.g. (Brandt, Szécsényi-Nagy, Roth, Alt, \& Haak, 2015, Klyosov, 2011c, 2015c,d) show, however, that the first inhabitants there were the Y Chromosome haplogroup I people, to whom later on the advent of agriculture admixed the Y Chromosome haplogroup R1 a people.

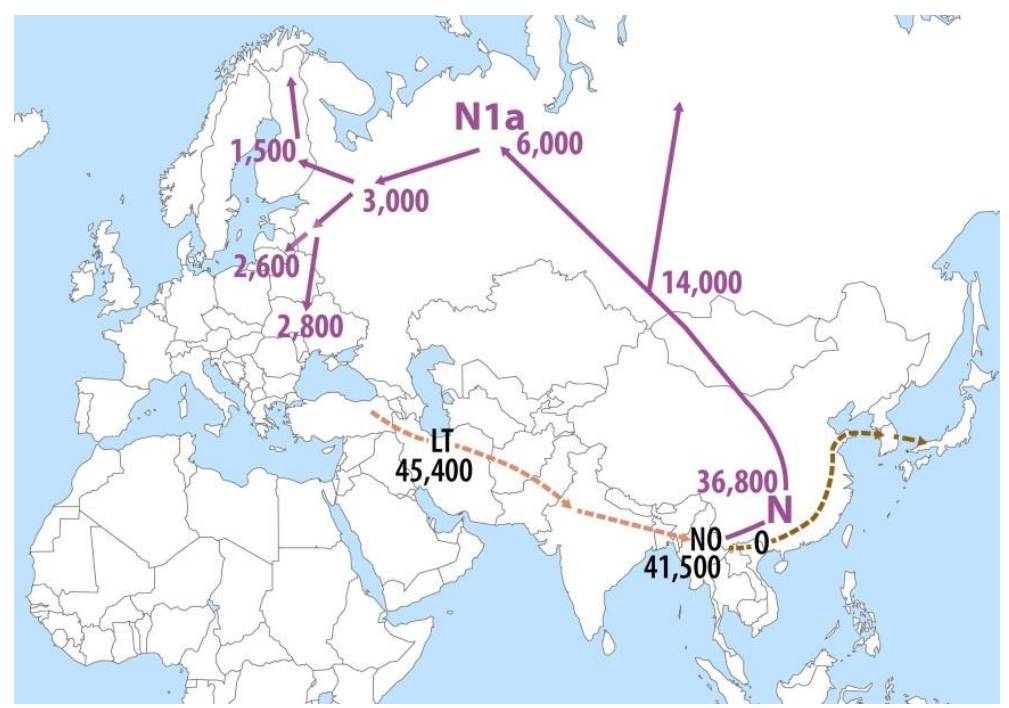

Map 11. Formation and expansion of people having the Y Chromosome haplogroup N (Klyosov, 2011c, 2015c,d) 
The Y Chromosome haplogroup N people formed in South-East Asia about 36,800 years ago, Map 11, and subsequently spread north and west reaching the Altai region about 14, 000 years ago, the Ugric region east of the Ural Mountains about 6,000 years ago, crossing the Ural Mountains about 3,000 years ago arriving to the Baltics about 2,500 years ago (Klyosov, 2011c, 2015c,d).

There is still open the question of who developed the agriculture in the Fertile Crescent. At the moment there seem to had been it the Y Chromosome haplogroup I people, whose remains have been observed in Anatolia about 8,000 years ago (Mathieson et al., 2015), whereas the G2a and R1a people seem to have arrived there when the agriculture was already developed. The diversity of mtDNA haplogroups among the agriculturalists arriving Europe and expanding there between 9,000 and 6,000 years ago $(\mathrm{H}, \mathrm{HV}, \mathrm{J}, \mathrm{K}, \mathrm{N}, \mathrm{T}, \mathrm{V}, \mathrm{X})$, compared to the uniqueness of the mtDNA haplogroup (U) and the Y Chromosome haplogroup (I) in the Paleolithic and Mesolithic Europe as well as the uniqueness of the arrived Y Chromosome haplogroups (G2a, R1a) (Brandt et al., 2015) indicates that the Fertile Crescend suffered several intrusions of different peoples contributing new mtDNA haplogroups but eliminating the previous Y Chromosome haplogroups.

\section{What Is the Meaning of These Data for the Question of Continuity vs. Migration in Europe?}

In Europe, the continuity of the Y Chromosome haplogroup I people is about 43,000 years, while their ancestors having the Y Chromosome haplogroup BT > CT lived there more than 68,000 years ago. The Y Chromosome haplogroup I people suffered during this time several bottleneck events, i.a. on the Y Chromosome haplogroup R1b people intrusions and on the Roman conquest.

Other Y Chromosome haplogroups, whose BT > CT > etc. ancestors survived in Europe, have most of their continuity outside Europe as presented in Map 3 through 11. Their continuity in Europe started as follows:

The continuity of YChromosome haplogroup G2a people, who are now in Europe a minority, lasts in Europe for about 9,000 to 6,000 years. The continuity of the Y Chromosome haplogroup R1a people, who are now characteristic for Slavs in Europe and Aryans in India, lasts in Europe for about 9,000 to 6,000 years as well. The continuity of the Y Chromosome haplogroup R1b people, who are now characteristic for western Europeans, lasts in the easternmost Europe for about 13,000 years, whereas in the western Europe for about 4,800 to 3,500 years. The continuity of the Y Chromosome haplogroup $\mathrm{N}$ people, who are now characteristic for the northeastern Europeans, lasts in Europe for about 3,000 to 1,500 years.

The Paleolithic Continuity have thus in Europe only the Y Chromosome haplogroup I people. Other ones have their Paleolithic Continuity outside Europe. In the Neolithic there arrived into Europe the Y Chromosome haplogroup G2a and R1a people, whereas the Y Chromosome haplogroup R1b people arrived into western Europe in the Bronze Age and the Y Chromosome haplogroup N people arrived into Europe in the Late Bronze Age / Iron Age.

For example, the fact that the Y Chromosome haplogroup N people arrived present European part of Russia and Baltic countries later than about 3,000 years ago and admixed to the inhabitants having the Y Chromosome haplogroups I and R1 a disproves the explanation valid till now, that there developed from the *Indo-European the Balto-Slavic linguistic complex, which splitted into Baltic and Slavic ones. The new genetic data presented above show that the primordial language in that area was Slavic and that Baltic derived from it on admixture of the Finno-Ugric people having the $\mathrm{Y}$ Chromosome haplogroup $\mathrm{N}$.

There was thus no split of the Indo-European language about 4,000 years ago, but on arrival of differently speaking people there took place the conversion of part of Proto-Slavic of that time into future Celtic, and still later into other non-Slavic languages.

These data have a substantial impact on the understanding of the development of languages in Europe. Let us look first at the Y Chromosome haplogroup N people, who were/are the speakers of Uralic languages. According to the Uralic Continuity Theory, cf. Alinei and Benozzo (2016), they would have occupied mid-eastern Europe in Paleolithic glacial times, and during the deglaciation of Northern Europe, in Mesolithic, would have followed the retreating icecap, eventually settling in their present territories. The DNA Genealogy data (Klyosov, 2015d) used to prepare Map 11, however, show that the Y Chromosome haplogroup N people developed in South-East Asia about 36,000 years ago, migrated north arriving the Altai region about 14,000 years ago, the Ugric territory east of the northern Ural about 6,000 years ago and crossing Ural toward west about 3,000 years ago and arriving the present Baltic and Trans-Carpathian area about 2,800 to 2,500 years ago, and Finland about 1,500 years ago. They have thus their Paleolithic, Mesolithic and Neolithic history outside Europe. Arriving into Europe about 3,000 years ago, they met there the Y Chromosome haplogroup I and R1 a people, which had settled previously different areas in different proportions. Let us have a look at the present situation, Table 1. 
Table 1. Present frequency of Y Chromosome haplogroups in northeastern Europe (ydna.eu, 2017) and the linguistic groups there

\begin{tabular}{lllllll}
\hline & Haplogroup & & & & Ratio \\
Country & $\mathrm{I}$ & $\mathrm{R} 1 \mathrm{a}$ & $\mathrm{R} 1 \mathrm{~b}$ & $\mathrm{~N}$ & Language & N/(I + R1a) \\
\hline Russia & 15.5 & 46 & 6 & 23 & Slavic & 0.37 \\
Belarus & 24 & 51 & 5.5 & 10 & Slavic & 0.13 \\
Ukraine & 17 & 45 & 7.5 & 7.5 & Slavic & 0.12 \\
Poland & 16 & 57.5 & 12.5 & 4 & Slavic & 0.05 \\
\hline Lithuania & 13 & 38 & 5 & 42 & Baltic & 0.82 \\
Latvia & 8 & 40 & 12 & 38 & Baltic & 0.79 \\
\hline Estonia & 18,5 & 32 & 8 & 34 & Finno-Ugric & 0.85 \\
Finland & 28,5 & 5 & 3.5 & 61.5 & Finno-Ugric & 1.83 \\
Saami & 27 & 13 & 7 & 53 & Finno-Ugric & 1.32 \\
\hline Sweden & 42 & 16 & 21.5 & 7 & Germanic & 0.12 \\
Norway & 36 & 25.5 & 32 & 2.5 & Germanic & 0.04 \\
\hline
\end{tabular}

As shown in Table 1, the present frequency of the Y Chromosome haplogroup $\mathrm{N}$ is prevailing over the joint frequency of the Y Chromosome haplogroups I and R1a in Finland and among the Saami people. In Baltic countries it is not prevailing. In Slavic and Germanic speaking countries it is much lower. One can conclude that where the incoming Y Chromosome haplogroup $\mathrm{N}$ people prevailed, there prevailed also their language. In Baltic countries where the frequency ratio $\mathrm{N} /(\mathrm{I}+\mathrm{R} 1 \mathrm{a})$ is slightly lower than 1, there either prevailed the Finno-Ugric language (Estonia) or there developed a Baltic language (Lithuania, Lat via). Where the frequency ratio N/(I+R1a) is low, there remained either a Slavic or a Germanic language. In the latter case there is characteristic a higher frequency of the Y Chromosome haplogroup R1b.

The fact that the Uralic speaking Y Chromosome haplogroup N people arrived present European part of Russia and Baltic countries later than about 3,000 years ago and admixed to the inhabitants having the Y Chromosome haplogroups I and R1a, disproves the explanation valid till now, that there developed from the *Indo-European the Balto-Slavic linguistic complex, which subsequently splitted into Baltic and Slavic ones. The new genetic data presented above show that the primordial language in that area was Slavic and that Baltic derived from it on admixture of the Uralic people having the Y Chromosome haplogroup N. There is interesting also that in Latvian there can be observed many Slovene dialectal words (Nikčević, 2006).

Next question are the YChromosome haplogroup G2a people. They arrived Europe about 9,000 to 7,500 years ago with agriculture and in the main valleys they were quite numerous. They seem to have been involved in the development of metalurgy and trade as well. On the expansion of the Y Chromosome haplogroup R1b people from the Iberian Peninsula after about 4,500 years ago they were largely exterminated. This kind of people are living now mainly in western Caucasian countries, especially in Ossetia.

An important part of the European population is represented now by the Y Chromosome haplogroup R1b people. In Europe, they are now mainly the speakers of Celtic, Germanic and Romance languages. Their origin and migrations, Map 8, show that they were originally the Altaic people speaking Turkic (Alinei, 1996-2000, 2000, 2003, Klyosov, 2011d). They arrived the Iberian Peninsula around 4,800 years ago, expanded across the Western Europe and reached Ireland and Scandinavia till about 3,500 years ago. On their way, they eliminated most of the previous, the $\mathrm{Y}$ Chromosome haplogroups I, G2a, and R1a having males, whereas the female population was not affected (Brandt et al., 2015). In areas, which were later not Romanized or Germanized, they are speaking now either Celtic or Basque. Whether Basque belongs to Indo-European or not, there is still being discussed (Forni, 2013a,b,c). On the other hand, there have been noticed similarities between Basque and Slavic (Jandáček \& Arko, 2002, Jandáček, 2003, 2004), between ancient Gaulish and Slavic (Ambrozic, 1999, 2000, 2002a,b, 2010, Serafimov, 2006, Serafimov \& Tomezzoli, 2010, Deacon, 2017), in denominations of toponyms, words and customs in the Slovenian way in Alps and on the British Isles (Tuma, 1923, 1925, 1926, Verbovšek, 1995, Bizjak, 2002, 2015, Rant A., 2007, 2008, 2014, Rant J., 2006, 2011, 2014, 2015). This indicates that prior to the intrusion of the Y Chromosome haplogroup R1b people, there was existing all over the Europe a Slavic substratum, which subsequently lost its Slavicity, but turned the Y Chromosome haplogroup R1b people from Altaic (Turkic) into the West-European Indo-European, which subsequently de veloped into Celtic resp. Basque.

Usually one considers that a female accepted into a family turns to the language spoken in the family. In Western Europe one has to consider also the possibility of the scenario that the offspring of a low number of Turkic speaking new local rulers having a substantial number of subjugated aboriginal females formed a language mix, which subsequently developed into "Celtic".

This opens also the question, which was the aboriginal Proto-Indo-European language. On the one hand, the Aryans 
arrived India from Europe (Rozhanskii \& Klyosov, 2009, 2012, Klyosov \& Rozhanskii, 2012a, Klyosov, 2014c, 2015a). On the other hand, the Y Chromosome haplogroup R1 a derived from the Y Chromosome haplogroup R1 somewhere near the Altai Mountains about 22,800 years ago, whereas the Y Chromosome haplogroup R1b derived from the Y Chromosome haplogroup R1 somewhere in the vicinity about 22,800 years ago as well (YFull, 2017). There are now spoken Turkic languages. When the Y Chromosome haplogroup R1b people arrived Western Europe after about 4,800 years ago, they were speaking Turkic (Altaic) (Alinei, 1996-2000, 2000, 2003, Klyosov, 2011d) in spite of having had lived away from the present Turkic speaking area for about ten millenia, Map 8.

It is hardly probable that on their formation from the Y Chromosome haplogroup R1 about 22,800 years ago in the Altai region, the Y Chromosome haplogroup R1 a people would speak already there Proto-Slavic whereas the YChromosome haplogroup R1b people would speak Proto-Turkic. Available data (Alinei, 1996-2000, 2000, 2003, Klyosov, 2011d) suggest the hypothesis that the Y Chromosome haplogroup R1a people turned Slavic on their way into Europe or in Europe till about 5,000 years ago, whereas the Y Chromosome haplogroup R1b people turned Indo-European within the Western Europe about 4,500 to 3,500 years ago. This question deserves additional studies.

This and the fact that there are observed several linguistic traces of probably Slavic origin in all languages in Europe (including the Basque: Jandáček and Arko (2002), Jandáček (2003, 2004)) indicates that the aboriginal Proto-Indoeuropean was Proto-Slavic and their speakers were the Y Chromosome haplogroup I, mtDNA haplogroup U people. The incomers, e.g. agriculturists of about 7,500 to 6,000 years ago were either already Proto-Slavic speaking or turned Proto-Slavic in contact with the Y Chromosome haplogroup I people or lived separated from them, whereas the Y Chromosome haplogroup R1b people turned Indo-European after about 4,800 years ago and formed the so-called Celtic languages.

Romanization and Germanization seem to have been later processes. The continuity of Greeks is about 3,700 years, whereas of Italic people about 3,200 years. For understanding the origin and de velopment of Germans and Germanic, it would be important to re-evaluate the explanation by Warnow, Ringe, \& Taylor (1996) that "It appears to point to a situation in which Germanic began to develop within the Satem Core (as evidenced by its morphology) but moved away before the final satem innovations. It then moved into close contact with the "western" languages ("Celtic" and Italic) and borrowed much of its distinctive vocabulary from them". Especially since there are similarities between German and Korean (Lie, 1991), as well as between Germanic and Chinese, where both of them are Kentum (Chang, 1988), and this indicates strongly that the ancestors of Germanic people were living in Far East and formed there the state of China. There persists the open question not only as to the degree to which Chinese was influenced by Germanic, which was studied by Chang (1988), but also as to the degree to which the Germanic was influenced by Korean, Chinese, and other Oriental languages. [Yet another question raised is: whether instead of Indo-Germanic some other designation such as Sino-Germanic would be more targeting and precise, Perdih \& Jandaček (2012)]. A provisional explanation would be saught for in the fact that the Proto-Slavic (or, one may prefer to say Aryan) people arrived Northern China about 3,500 years ago (Klyosov, 2014c, 2015a, 2016a,b), came there in contact with Chinese (Chang, 1988) and other people of the area, and after accepting parts of the Oriental languages, part of them turned about 3,000 years ago west into Europe, where they mixed with Celtic people and conquered the areas which then became Germanic.

For the origin of the Romance language group one has to take into account the possibility that they formed after the rout of part of the defeated army of the "Peoples from beyond the Sea" onto the Apennine Peninsula followed by subsequently subduing the local indigenous peoples and later as the Roman Empire expanded elsewhere in Europe. A detailed analysis for subclades and extended haplotypes of a sufficient number of individuals of haplogroups $\mathrm{E}, \mathrm{J}$ and $\mathrm{T}$ in different localities in Europe for their times to the common ancestors may give some usefull indications about that.

Some characteristics similar to Latin can be observed in the Baltic languages, including Estonian, but not in the Finnish and Slavic ones. Data on the prevalence, the emergence and de velopment of the Y Chromosome haplogroup T, which were collected by Labai (2012), and the Akkadian etymology of numerous Greek and Latin words (Semerano, 1984, 1994) may indicate the direction in which to look for the origin of the Latin heritage. Till recently was not known the fact that the people Laki in Dagestan are the last remnant of speakers of the Akkadian language (Klyosov, 2011e, Omarieva, 2011 a,b,c, 2012, 2013a,b,c, 2014, 2015, 2016, Luguev, 2011, Rozhanskii, 2011), whose language could help to better know the former Akkadian language and the akkadic etymology of numerous Greek and Latin words (Semerano, 1984, 1994). This indicates also the solution of the question of the origin of the words Lah < Lak and Achaia < Akkad.

The DNA Genealogy data seem thus to provide an essetial contribution to the explanations of the origin and development of peoples and languages. Some trials to put together the data provided by the DNA Genealogy, archaeology and linguistics and to look for a better explanation have been already made (Klyosov \& Tomezzoli, 2013, Klyosov, 2016a,b) and similar efforts are to be continued from all sides, which have relevant data. The Jandáček's 
Core-Peripheral paradigm of the Indo-Europen languages (Jandáček, 2000, 2004, Jandáček \& Perdih, 2008, Perdih \& Jandáček, 2012) is in line with the combination of the linguistic and DNA Genealogy data presented above.

\section{Conclusion}

The aboriginal Europeans were the Y Chromosome haplogroup I people. They were the Proto-Indo-Europeans and the Proto-Slavic speakers. In contact with newcomers of other language groups mixing took place. Either the newcomers were absorbed into the autochthonous Proto-Slavic community, or the native Proto-Slavic population was so effected by the immigrants that they lost their Slavic identity forming a language, which remained Indo-European but no longer recognizable as specifically Slavic.

The Kurgan Theory and the Pontic Steppe Theory of the Indo-European origin failed completely. The Neolithic Discontinuity Theory theory gives only a part of the necessary explanation. The Paleolithic Continuity Paradigm has to be adapted to the data presented by the DNA Genealogy about the times and areas of past events.

There should be made a synergistic combination of the DNA Genealogy data and of the linguistic data, which are the basis of the Paleolithic Continuity Paradigm. The DNA Genealogy data give the timeframe and probable localities of the events, which are to be considered in explanation of linguistic data, which are the basis of the Paleolithic Continuity Paradigm.

The synergistic combination of the DNA Genealogy data and the data on which the Paleolithic Continuity Paradigm is based will give a better time and space resolved presentation of when and where some linguistic event took place.

The interpretations based on the synergistic combination of the DNA Genealogy data and of the linguistic data, which are the basis of the Paleolithic Continuity Paradigm are to be thoroughly re-evaluated also from the points of view of data of other disciplines, e.g. anthropology, archaeology, oral tradition, etc, taking as arguments not the interpretations considered valid till now, but data. The new evaluation has to be based on data only and not on the obsolet interpretations. Such a combination of data of different disciplines should be the subject of further studies.

\section{Acknowledgement}

Drawing of Maps 2 through 11 by S. Kodrič, Založništvo Jutro, Ljubljana, Slovenia, is thankfully acknowledged.

\section{References}

(Remark: Papers published in Вестник Российской Академии ДНК-генеалогии and Вестник Академии ДНК-генеалогии are accessible on http://dna-academy.ru/proceedings/; papers published in Zbornik ... are accessible on http://www.korenine.si/zborniki/)

Alinei, M. (1996, 2000). Origini delle lingue d'Europa, 2 vol.: vol. I: La teoria della continuità; vol. II: Continuità dal Mesolitico all'età del Ferro nelle principali aree etnolinguistiche. Bologna: Il Mulino.

Alinei, M. (2000). An alternative model for the origins of European peoples and languages: the continuity theory. Quaderni di Semantica, 21, 21-50.

Alinei, M. (2003). Interdisciplinary and linguistic evidence for Paleolithic continuity of Indo-European, Uralic and Altaic populations in Eurasia, with an excursus on Slavic ethnogenesis. Conference "Ancient settlers in Europe". Kobarid; Quaderni di semantica, 24, 187-216. http://www.continuitas.org/texts/alinei_interdisciplinary.pdf

Alinei, M., \& Benozzo, F. (2016). The Paleolithic Continuity Paradigm for the Origins of Indo-European Languages. An Introduction in progress. www.continuitas.org/intro.html

Ambrozic, A. (1999). Adieu to Brittany. Toronto: Cythera Press.

Ambrozic, A. (2000). Journey back to the Garumna. Toronto: Cythera Press.

Ambrozic, A. (2002a). Gordian Knot Unbound. (pp. 1-57). Toronto: Cythera Press.

Ambrozic, A. (2002b). Etymological Parallelism in Inscriptions, Tribal Names, Toponyms, Hydronyms, and Word Compounding from Ancient Gaul. Zbornik prve mednarodne konference Veneti v etnogenezi srednjeevropskega prebivalstva [Proceedings of the first international topical conference The Veneti within the Ethnogenesis of the Central-European Population]. (pp. 131-149). Ljubljana: Založništvo Jutro. http://www.korenine.si/zborniki/zbornik01/htm/ambrozic_gaul.htm

Ambrozic, A. (2010). The Templar's curse. Toronto: Cythera Press.

Bizjak, J. (2002). Prispevek k razpravi o etnogenezi prebivalstva v Alpah, Zbornik prve mednarodne konference Veneti v etnogenezi srednjeevropskega prebivalstva [Proceedings of the first international topical conference The Veneti within the Ethnogenesis of the Central-European Population]. (pp. 196-198). Ljubljana: Založništvo Jutro. http://www.korenine.si/zborniki/zbornik01/htm/bizjak.htm 
Bizjak, J. (2015). Slovenski toponimi v vzhodnih Alpah [Slovene toponyms in the eastern Alps]. Dr. Henrik Tuma, zamolčani raziskovalec avtohtonega slovenskega krajevnega imenoslovja v Alpah. (pp. 35-47). Ljubljana: Nova obzorja.

Brandt, G., Szécsényi-Nagy, A., Roth, Ch., Alt, W. K., \& Haak, W. (2015). Human paleogenetics of Europe - The known knowns and the known unknowns. J. Human Evolution 79, 73-92. https://doi.org/10.1016/j.jhevol.2014.06.017

Chang, T. (1988). Indo-European vocabulary in Old Chinese. Sino-Platonic Papers, 7, 1-56. http://sino-platonic.org/complete/spp007_old_chinese.pdf

Deacon, M. (2017). Wendish in ancient Gaul. Zbornik štirinajste mednarodne konference Korenine Slovenov in Evropejcev [Proceedings of the Fourteenth International Topical Conference Origin of Slovenes and Europeans]. (pp. 99-123). Ljubljana: Založništvo Jutro.

Forni, G. (2013a). Evidence for Basque as an Indo-European Language. J. Indo-European Studies, 41, 39-180.

Forni, G. (2013b). AReply to the Critics. J. Indo-European Studies, 41, 268-320.

Forni, G. (2013c). A First Etymological Dictionary of Basque as an Indo-European Language. http://www.amazon.it/dp/1499595468.

Fu, Q., Mittnik, A., Johnson, P. L., Bos, K., Lari, M., Bollongino, R., ... Krause, J. (2013). Arevised timescale for human evolution based on ancient mitochondrial genomes. Curr. Biol., 23, 553-559. https://doi.org/10.1016/j.cub.2013.02.044

Fu, Q., Posth, C., Hajdinjak, M., Petr, M., Mallick, S., Fernandes, D., ... Reich, D. (2016). The genetic history of Ice Age Europe. Nature, 524, 216-219. https://doi.org/10.1038/nature14558

Jandáček, P. (2000). Origin of Speeches, Los Alamos. Revised (2008): http://www.veneti.info/index.php?view=article\&catid=25\%3 Alinguistics\&id=126\%3Aorigin-of-the-speeches\&opt ion=com_content $\&$ Itemid $=165$

Jandáček, P., \& Arko, L. (2002). Linguistic connections between Basques and Slavs (Veneti) in antiquity. Zbornik prve mednarodne konference Veneti v etnogenezi srednjeevropskega prebivalstva [Proceedings of the first international topical conference The Veneti within the Ethnogenesis of the Central-European Population]. (pp. 151-166). Ljubljana: Založništvo Jutro. http://www.korenine.si/zborniki/zbornik01/htm/jandacek_linguistic.htm

Jandáček, P. (2003). Equipment of Ötzi in Basque and Slavic. Zbornik posveta Praprebivalstvo na tleh Srednje Evrope [Proceedings of the conference Ancient Settlers of Central Europe]. (pp. 17-20). Ljubljana: Založništvo Jutro. http://www.korenine.si/zborniki/zbornik02/jandacek02.htm

Jandáček, P. (2004). Base Ten counting as the extension of the archetypical Base Five system of Basques and Slavs. Zbornik mednarodnega posveta Sledovi evropske preteklosti [Proceedings International workshop Traces of European Past]. (pp. 74-84). Ljubljana: Založništvo Jutro. http://www.korenine.si/zborniki/zbornik03/jandacek_baseten.htm

Jandáček, P., \& Perdih, A. (2008). A novel view of the origins, development and differentiation of Indo-Europeans, Zbornik šeste mednarodne konference Izvor Evropejcev [Proceedings of the sixth international topical conference Origin of Europeans]. (pp. 88-98). Ljubljana: Založništvo Jutro. http://www.korenine.si/zborniki/zbornik08/novel_ie_view.pdf

Jandáček, P., \& Perdih, A. (2017). Words for the Animal Elephant/Mammoth in Relation to the DNA Genealogy Data. Advances in Anthropology, 7, 251-272. https://doi.org/10.4236/aa.2017.74014

Klyosov, A. A. (2008). Загадки «западноевропейской» гаплогруппы R1b. Вестник Российской Академии ДНК-генеалогии, 1, 568-630.

Klyosov, A. A. (2009a). DNA Genealogy, mutation rates, and some historical evidence written in the Y-Chromosome: I. Basic principles and the method. J. Genet. Geneal., 5, 186-216.

Klyosov, A. A. (2009b). DNA Genealogy, mutation rates, and some historical evidences written in Y-chromosome. II. Walking the map. J. Genet. Geneal., 5, 217-256.

Klyosov, А. А. (2009c). Гаплотипы Иберии и анализ истории популяций басков, сефардов и других групп Испании и Португалии. Вестник Российской Академии ДНК-генеалогии, 2, 390-421.

Klyosov, A. А. (2010a). Нарlogroup I. Вестник Российской Академии ДНК-генеалогии, 3, 96-158.

Klyosov, A. A. (2010b). Migration route of R1b haplogroup to Europe and its populating in Europe. Acritical analysis of Myres et al paper “A Major Y chromosome haplogroup R1b...” (Eur. J. Hum. Genetics, 26 August 2010). Вестник 
Российской Академии ДНК-генеалогии, 3, 1652-1675.

Klyosov, A. A. (2011a). Biological Chemistry as a Foundation of DNA Genealogy: the Emergence of "Molecular History". Biokhimiya, 76, 636-653 (Biochemistry https://doi.org/10.1134/S0006297911050026

Klyosov, A. A. (2011b). Haplotypes of R1b1a2-P312 and related subclades: origin and "ages" of most recent common ancestors. Вестник Российской Академии ДНК-генеалогии, 4, 1127-1195.

Klyosov, A. А. (2011c). «Угро-финская» и «южно-балтийская» ветви гаплогруппы N1с1 и их гаплотипы. Вестник Российской Академии ДНК-генеалогии, 4, 1604-1626.

Klyosov, A. A. (2011d). Haplogroup R1b as a carrier of Proto-Türkic languages, aka Dene-Caucasian languages, aka Erbin, that is a non-IndoEuropean language in its dynamics during 16,000 to 3,000 years before present. Becmник Российской Академии ДНК-генеалогии, 4, 1716-1773.

Klyosov, A. А. (2011e). Предисловие редактора. Лаки и аккадцы древнего Шумера. Вестник Российской Академии ДНК-генеалогии, 4, 1580-1583.

Klyosov, A. A. (2012a). Ancient History of the Arbins, Bearers of Haplogroup R1b, from Central Asia to Europe, 16,000 to 1500 Years before Present. Advances in Anthropology, 2, 87-105. https://doi.org/10.4236/aa.2012.22010

Klyosov, A. A. (2012b). Динарская (восточно-европейская) и «островные» ветви гаплогруппы I2a. Вестник Академии ДНК-генеалогии, 5, 1304-1317.

Klyosov, A. А. (2012c). Гаплогруппы и гаплотипы Кавказа. Вестник Академии ДНК-генеалогии, 5, $1005-1036$.

Klyosov, A. A. (2013). Миграционный профиль субкладов гапло-группы R1b согласуется с северо-африканским маршрутом эрбинов от Ближнего Востока до Пиреней и далее в континентальную Европу. Вестник Академии ДНК-генеалогии, 6, 727-729.

Klyosov, A. A. (2014a). Reconsideration of the "Out of Africa" Concept as Not Having Enough Proof. Advances in Anthropology, 4, 18-37. https://doi.org/10.4236/aa.2014.41004

Klyosov, А. А. (2014b). Ископаемые гаплогруппы и гаплотипы. Вестник Академии ДНК-генеалогии, 7, $1135-1184$.

Klyosov, A. А. (2014c). ДНК-генеалогия как молекулярная история. Часть 1. Иллюстрации к киргизскому Проекту FTDNA, Вестник Академии ДНК-генеалогии, 7, 1842-1887.

Klyosov, А. А. (2015a). ДНК-генеалогия для всех и для каждого (часть 1). http://pereformat.ru/2015/08/klin-01/, 4.08.2015

Klyosov, А. А. (2015b). ДНК-генеалогия для всех и для каждого (часть 2). http://pereformat.ru/2015/08/klin-02/, 12.08.2015

Klyosov, А. А. (2015c). ДНК-генеалогия для всех и для каждого (часть 3). http://pereformat.ru/2015/08/klin-03/, 26.08.2015

Klyosov, A. A. (2015d). Холмик родил мышь, или Широковещательная статья про балто-славян. http://pereformat.ru/2015/09/balto-slavyanel, 13.09.2015

Klyosov, A. А. (2016a). Миграции ариев от 6000 до 3000 лет назад - как их видит ДНК-генеалогия, археология и лингвистика. Часть 1. Вестник Академии ДНК-генеалогии, 9, 2-29.

Klyosov, A. А. (2016b). Миграции ариев от 6000 до 3000 лет назад - как их видит ДНК-генеалогия, археология и лингвистика. Часть 2. Вестник Академии ДНК-генеалогии, 9, 187-240.

Klyosov, A. A. (2016c). http://pereformat.ru/2016/09/rezultaty-testirovaniya/\#comment-16160, 11.9.2016, 5:41

Klyosov, A. A., \& Rozhanskii, I. L. (2012a). Haplogroup R1a as the Proto Indo-Europeans and the Legendary Aryans as Witnessed by the DNA of Their Current Descendants. Advances in Anthropology, 2, 1-13. https://doi.org/10.4236/aa.2012.21001

Klyosov, A. A., \& Rozhanskii, I. L. (2012b). Re-Examining the "Out of Africa" Theory and the Origin of Europeoids (Caucasoids) in Light of DNA Genealogy. Advances in Anthropology, 2, 80-86. https://doi.org/10.4236/aa.2012.22009

Klyosov, A. A., Rozhanskii, I. L., \& Ryabchenko, L. E. (2013). Re-Examining the Out-of-Africa Theory and the Origin of Europeoids (Caucasoids). Part 2*. SNPs, Haplogroups and Haplotypes in the Y Chromosome of Chimpanzee and Humans. Вестник Академии ДНК-генеалогии, 6, 667-704.

Klyosov, A. A., \& Tomezzoli, G. T. (2013). DNAGenealogy and Linguistics. Ancient Europe. Advances in Anthropology, 
3, 101-111. https://doi.org/10.4236/aа.2013.32014; Вестник Академии ДНК-генеалогии, 6, 1051-1076. https://doi.org/10.4236/aa.2013.32014

Labai, A. А. (2012). Гаплогруппа Т (в поисках корней). Вестник Академии ДНК-генеалогии, 5, 344-357.

Lie, K-H. (1991). Verbale Aspektualität im Koreanischen und im Deutschen, Tübingen: Niemeier. https://doi.org/10.1515/9783111356518

Luguev, R. G. (2011). Послесловие-комментарий. Вестник Российской Академии ДНК-генеалогии, 4, 1592-1593.

Mathieson, I., Lazaridis, I., Rohland, N., Mallick, S., Patterson, N., Roodenberg, S. A., ... Reich, D. (2015). Eight thousand years of natural selection in Europe. Nature, 528, 499-503. https://doi.org/10.1038/nature 16152

Nikčević, V. P. (2006). Praizvor, prototip i praiskon izgovora slovjenskog jata. Zbornik četrte mednarodne konference Evropski staroselci [Proceedings of the Fourth International Topical Conference Ancient Inhabitants of Europe]. (pp. 205-224). Ljubljana: Založništvo Jutro. http://www.korenine.si/zborniki/zbornik06/

Omarieva, R. A. (2011a). Об удивительных и неожиданных языковых совпадениях между лакским и аккадским языками. Вестник Российской Академии ДНК-генеалогии, 4, 1584-1592.

Omarieva, R. A. (2011b). Об удивительных и неожиданных языковых совпадениях между лакским и аккадским языками (Продолжение). Вестник Российской Академии ДНК-генеалогии, 4, 1776-1782.

Omarieva, R. A. (2011c). Об удивительных и неожиданных языковых совпадениях между лакским и аккадским языками. Топоним ика и личные имена лаков (Окончание). Вестник Российской Академии ДНК-генеалогии, 4, 2080-2087.

Omarieva, R. (2012). Сравнение аккадской, лакской и арамейской лексики на основе урока для изучения сирияк современного языка ассирийцев. Вестник Академии ДНК-генеалогии, 5, 241-256.

Omarieva, R. (2013a). Лакский язык - ключ к пониманию клинописей древней Месопотамии. Вестник Академии ДНК-генеалогии, 6, 374-385.

Omarieva, R. (2013b). Лакский язык - ключ к пониманию клинописей Месопотамии (триста слов). Вестник Академии ДНК-генеалогии, 6, 730-754.

Omarieva, R. (2013c). Моё исследование аккадского языка. Леки - осколок Шумера в высокогорьях Кавказа. Вестник Академии ДНК-генеалогии, 6, 1871-1883.

Omarieva, R. (2014). Топонимика и имена лаков, происхождение. Этноним лек. Вестник Академии ДНК-генеалогии, 7, 598-610.

Omarieva, R. (2015). Микротопонимика сел Лакии: отражение Шумера и Месопотамии в целом. Вестник Академии ДНК-генеалогии, 8, 2-54.

Omarieva, R. (2016). Язык шумеров: термин Lequ и другие. Связь с санскритом и другими языками. Вестник Академии ДНК-генеалогии, 9, 241-257.

Perdih, A. (2016). Izvor Slovencev in drugih Evropejcev [Origin of Slovenes and other Europeans] (2 ${ }^{\text {nd }}$ ed.). Ljubljana: Založništvo Jutro.

Perdih, A. \& Jandáček, P. (2012). New understanding of Western Eurasia in prehistoric times. Вестник Академии ДНК-генеалогии, 5(2), 38-94.

Rant, A. (2007). Surnames in Swansea Area (Wales, Great Britain) and in Slovenia. Zbornik pete mednarodne konference Izvor Evropejcev [Proceedings of the Fifth International Topical Conference Origin of Europeans]. (pp. 207-212). Ljubljana: Založništvo Jutro. http://www.korenine.si/zborniki/zbornik07/a_rant07.pdf

Rant, A. (2008). Karni in Venetiv Britaniji in Alpah. Žirovnica: Prorang.

Rant, A. (2014). Karni in Veneti v Britaniji in Alpah. Slovenci - kdo smo in od kdaj smo tu? (pp. 73-92). Ljubljana: Založništvo Jutro.

Rant, J. (2006). Sledi slovanskega jezikovnega substrata v jeziku sodobnih Ladincev. Zbornik četrte mednarodne konference Evropski staroselci [Proceedings of the Fourth International Topical Conference Ancient Inhabitants of Europe]. (p. 195). Ljubljana: Založništvo Jutro. http://www.korenine.si/zborniki/zbornik06/

Rant, J. (2011). Imena odkrivajo zgodovino: Nekaj jezikovnih dokazov o avtohtonosti Slovencev v Vzhodnih Alpah in okolici. Ljubljana: Založništvo Jutro.

Rant, J. (2014). Imena odkrivajo zgodovino: Nekaj jezikovnih dokazov o avtohtonosti Slovencev v Vzhodnih Alpah in okolici, Slovenci - kdo smo in od kdaj smo tu? (pp. 93-236). Ljubljana: Založništvo Jutro. 
Rant, J. (2015). Sledovi slovenskega jezikovnega substrata v narečjih Retoromanov in Ladincev. Dr. Henrik Tuma, zamolčani raziskovalec avtohtonega slovenskega krajevnega imenoslovja v Alpah, (pp. 49-64). Ljubljana: Nova obzorja.

Rozhanskii, I. L. (2011). Отзыв на статью Р А Омариевой «Об удивительных и неожиданных языковых совпадениях между лакским и аккадским языками». Вестник Российской Академии ДНК-генеалогии, 4, 1594-1603.

Rozhanskii, I. L., \& Klyosov, A. A. (2009). Haplogroup R1a1: haplotypes, lineages, history, geography. Вестник Российской Академии ДНК-генеалогии, 2, 974-1099.

Rozhanskii, I. L., \& Klyosov, A. A. (2012). Haplogroup R1a, its subclades and branches in Europe during the last 9000 years. Advances in Anthropology, 2, 139-156. https://doi.org/10.4236/aa.2012.23017

Rozhanskii, I. L. (2016). http://pereformat.ru/2016/09/rezultaty-testirovaniya/\#comment-16154, 10.9. 2016, 11:07.

Semerano, G. (1984, 1994). Le origini della cultura Europea. Firenze: Leo S. Olschki Ed.

Serafimov, P. (2006). Celto-Slavic Similarities. Zbornik četrte mednarodne konference Evropski staroselci [Proceedings of the Fourth International Topical Conference Ancient Inhabitants of Europe]. (pp. 82-116). Ljubljana: Založništvo Jutro. http://www.korenine.si/zborniki/zbornik06/serafimov_celtoslav06.pdf

Serafimov, P., \& Tomezzoli, G. (2010). Slavic influences in the ancient Gaul. Zbornik osme mednarodne konference Izvor Evropejcev [Proceedings of the Eighth International Topical Conference Origin of Europeans], (pp. 87-97). Ljubljana: Založništvo Jutro. http://www.korenine.si/zborniki/zbornik10/seraf_slavic_gaul.pdf

Tuma, H. (1923). Krajevno imenoslovje. Jadranski almanah, 127-158.

Tuma, H. (1925). Toponomastika. Geografski vestnik, 2, 86-97.

Tuma, H. (1926). Slovenska imena v ladinskem in bavarskem narečju. Planinski vestnik, 7, 157-162.

Verbovšek, L. (1995). Кoтu (ni)smo tujci? Ljubljana: Založništvo Jutro.

Warnow, T., Ringe, D., \& Taylor, A. (1996). Reconstructing the evolutionary history of natural languages. Proceedings of the ACM/SIAM Symposium on Discrete Algorithms, http://repository.upenn.edu/ircs_reports/11

ydna.eu. (2017). http://www.eupedia.com/europe/european_y-dna_haplogroups.shtml, 28.4. 2017.

YFull. (2017). http://www.yfull.com/tree/, 28.4.2017.

Yurkovets, V. Р. (2012). Ладожская импактно-вулканическая структура. Вестник Академии ДНК-генеалогии, 5, 1059-1085.

Yurkovets, V. P. (2014). Признаки импактного метаморфизма в породах Ладожской импактно-вулканической структуры. Вестник Академии ДНК-генеалогии, 7, 263-302.

Yurkovets, V. Р. (2015). Климатическая катастрофа гаплогруппы «Бета». Вестник Академии ДНК-генеалогии, 8 , 376-432.

Yurkovets, V. P., \& Vasilenko, S. I. (2017). ДНК-генеалогия, палеоклимат и геоморфология. Гидродинамический карст. Вестник Академии ДНК-генеалогии, 10, 1412-1442.

Zohary, D., \& Hopf, M. (2004). Domestication of plants in the Old World. Oxford: Oxford University Press.

\section{Copyrights}

Copyright for this article is retained by the author(s), with first publication rights granted to the journal.

This is an open-access article distributed under the terms and conditions of the Creative Commons Attribution license which permits unrestricted use, distribution, and reproduction in any medium, provided the original work is properly cited. 